\title{
Implementasi Manajemen Berbasis Madrasah dalam Meningkatkan output/Lulusan Siswa di MA Mathlaul Anwar Kepuh Serang Banten
}

\author{
Mohammad Farkhan \\ Universitas Islam Negri Sunan Kalijaga Yogyakarta \\ 19204090007@uin-suka.ac.id
}

\begin{abstract}
This study was conducted to determine how the implementation of madrasa-based management and the results of this implementation in increasing the output/graduates of students at $M A$ Mathlaul Anwar Kepuh Serang Banten. This research is a type of descriptive qualitative research. Data were collected by means of interviews, field observations, and documentation. Data analysis was carried out by reducing data from interviews, then presenting data and finally drawing conclusions as a form of answers to the background of the research problem. The implementation of madrasa-based management at MA Mathlaul Anwar Kepub Serang Banten includes, curriculum management, student management, management of educators and education, management of facilities and infrastructure, financial management, and management of relations with the community running well from planning to evaluation. The implementation of madrasa-based management in increasing student output/graduates at MA Mathlaul Anwar Kepuh is generally carried out well, as evidenced by the presence of several students who can continue their education at public and private universities. There are even some students who can continue their studies with the tahfidz scholarship program abroad. Being able to improve students' non-academic achievements can be seen from the increasing achievements achieved by MA Mathlaul Anwar Kepuh even though they have not been able to improve academic achievement at MA Mathlaul Anwar seen from the lack of increase in UN scores from the previous year.
\end{abstract}

Keywords: Madrasa-Based Management, Graduate Students

\begin{abstract}
Abstrak : Penelitian ini dilakukan untuk mengetahui bagaiamana implementasi manajemen berbasis madrasah dan hasil dari implementasi tersebut dalam meningkatkan output/lulusan siswa di MA Mathlaul Anwar Kepuh Serang Banten. Penelitian ini merupakan jenis penelitian kualitatif deskriptif. Pengambilan data dilakukan dengan cara wawancara, observasi lapangan, dan dokumentasi. Anlisis data dilakukan dengan cara mereduksi data dari hasil wawancara, kemudian penyajian data dan yang terakhir penarikan kesimpulan sebagai bentuk jawaban dari latar belakang masalah penelitian. Implementasi manajemen berbasis madrasah di MA Mathlaul Anwar Kepuh Serang Banten meliputi, manajemen kurikulum, manajemen peserta didik, manajemen tenaga pendidik dan kependidikan, manajemen sarana dan prasarana, manajemen keuangan, dan manajemen hubungan dengan masyarakat berjalan dengan baik dari perencanaan hingga evaluasi. Implementasi manajemen berbasis madrasah dalam meningkatkan output/lulusan siswa di MA Mathlaul Anwar Kepuh secara umum dilakukan dengan baik dibuktikan dengan adanya beberapa siswa yang dapat melanjutkan pendidikan di perguruan tinggi negeri maupun swasta. Bahkan ada beberapa siswanya yang dapat
\end{abstract}

MANAZHIM : Jurnal Manajemen dan Ilmu Pendidikan

Volume 3, Nomor 2, Agustus 2021; 214-235

https:// ejournal.stitpn.ac.id/index.php/manazhim 
melanjutkan studi dengan program beasiswa tahfidz di luar negri. Mampu meningkatkan prestasi non akademik siswa dilihat dari meningkatnya prestasi yang diraih MA Mathlaul Anwar Kepuh walaupun belum mampu meningkatkan prestasi akademik di MA Mathlaul Anwar dilihat dari tidak meningkatnya nilai UN dari tahun sebelumnya.

Kata Kunci: Manajemen Berbasis Madrasah, Lulusan Siswa

\section{PENDAHULUAN}

Pendidikan merupakan aspek kehidupan yang bersifat fungsional bagi setiap manusia dan memiliki kedudukan strategis untuk mencerdaskan kehidupan bangsa. ${ }^{1}$ Pendidikan nasional yang bermutu salah satunya dapat dilihat dari keluarannya (output) yang bermutu, yakni dilihat dari lulusan bermutu yang diakui di tingkat nasional, regional, dan internasional. Dalam konteks ini, pendidikan nasional yang lulusannya bermutu merupakan suatu keniscayaan karena tanpa menghasilkan lulusan yang bermutu, program pendidikan bukan dipandang sebagai investasi sumberdaya manusia yang dapat meningkatkan daya saing bangsa, melainkan dipandang sebagai pemborosan dilihat dari segi biaya, tenaga, dan waktu. Selanjutnya untuk menghasilkan lulusan bermutu, dalam sistem pendidikan nasional perlu dipertajam upaya-upaya penjaminan mutu (quality assurance). Penjaminan mutu mengharuskan upaya penentuan standar kemampuan dari sisi masukan (entry leved) pembelajar untuk setiap jenjang pendidikan, standar isi yang terukur, standar proses yang mengacu pada pencapaian standar isi, standar kompetensi lulusan yang secara sistemik berkaitan dengan standar isi dan standar-standar lain, seperti standar pendidik, sarana dan prasarana serta pembiayaan yang difokuskan guna menghasilkan output pendidikan yang juga bermutu. $^{2}$

Dalam buku Fatah Syukur yang berjudul "Manajemen Pendidikan Berbasis Pada Madrasah" dijelaskan bahwa salah satu persoalan pendidikan yang sedang dihadapi bangsa kita adalah persoalan mutu pendidikan pada setiap jenjang dan satuan pendidikan. Berbagai usaha telah dilakukan untuk meningkatkan mutu pendidikan

\footnotetext{
${ }^{1}$ Siti Masruroh "Manajemen Peningkatan Mutu Berbasis Madrasab Di MTs Negri Karanganyar Purbalingga” (S. Pd script, IAIN Purwokerto, 2012), 1

2 Tjala, Awaluddin. "Potret Mutu Pendidikan Indonesia Ditinjau dari Hasil-hasil Studi Internasional.", journal of repository.ut.ac.id, (2008): 3.
} 
nasional, antara lain melalui berbagai pelatihan dan peningkatan kompetensi guru, pengadaan buku dan alat pelajaran, perbaikan sarana dan prasarana pendidikan, dan peningkatan mutu manajemen sekolah. Namun demikian, indikator mutu pendidikan belum menunjukkan peningkatan yang berarti. Sebagian sekolah, terutama di kotakota, menunjukkan peningkatan mutu pendidikan yang cukup menggembirakan, namun sebagian besar lainnya masih memprihatinkan. Dalam hal ini, sekolah sebagai unit pelaksana pendidikan formal terdepan dengan berbagai keragaman potensi anak didik yang memerlukan layanan pendidikan yang beragam, kondisi lingkungan yang berbeda satu dengan yang lainnya, maka sekolah harus dinamis dan kreatif dalam melaksanakan perannya untuk mengupayakan peningkatan kualitas atau mutu pendidikan. Hal ini akan dapat dilaksanakan jika sekolah dengan berbagai keragamannya itu, diberikan kepercayaan untuk mengatur dan mengurus dirinya sendiri sesuai dengan kondisi lingkungan dan kebutuhan anak didiknya.

Madrasah adalah salah satu lembaga pendidikan Islam formal di Indonesia yang terintegrasi dalam sistem pendidikan nasional. Madrasah merupakan bagian dari Sistem Pendidikan Nasional, oleh karena itu tujuannya mengacu pada pendidikan nasional yang ditetapkan dalam GBHN dan Undang - Undang No. 20/2003 tentang sistem pendidikan nasional, yaitu bertujuan untuk berkembangnya potensi peserta didik agar menjadi manusia yang beriman, dan bertakwa pada Tuhan Yang Maha Esa, berakhlak mulia, sehat, berilmu, cakap, kreatif, mandiri, dan menjadi warga negara yang demokratis serta bertanggung jawab. ${ }^{3}$ Mengingat bahwa lembaga pendidikan (madrasah) merupakan lembaga pendidikan yang berciri khas pendidikan agama Islam, tentunya mempunyai muatan lebih pada pendidikan agama. Mutu lulusan madrasah saat ini dituntut mampu mengamalkan ajaran agama dan menguasai ilmu pengetahuan. ${ }^{4}$ Dalam hal peningkatan mutu madrasah, termasuk di dalamnya mutu output/lulusan, telah diterapkan adanya MBM atau Manajemen Berbasis Madrasah. Tujuan dari adanya MBM ini adalah untuk meningkatkan efisiensi, mutu, dan pemerataan pendidikan. MBM merupakan paradigma baru manajemen pendidikan, yang memberikan otonomi

${ }^{3}$ Yusuf Umar, Manajemen Pendidikan Madrasah Bermutu, (Bandung: Refika Aditama 2016), hlm. $1-4$.

${ }^{4}$ Nur Zazin, Gerakan Menata Mutu Pendidikan Teori \& Aplikasi, (Yogyakarta: AR-RUZZ MEDIA, 2011), hlm. 73. 
luas pada madrasah, dan pelibatan masyarakat dalam kerangka kebijakan pendidikan nasional. MBM muncul karena beberapa alasan. Pertama, terjadinya ketimpangan kekuasaan dan kewenangan yang terlalu terpusat pada atasan yang mengesampingkan bawahan. Kedua, kinerja pendidikan yang tidak kunjung membaik bahkan cenderung menurun. Ketiga, adanya kesadaran para birokrat dan desakan dari para pecinta pendidikan untuk merestrukturisasi pengelolaan pendidikan. Dengan munculnya MBM ini diharapkan bahwa masing-masing sekolah atau madrasah mampu mengelola dan mengoptimalkan pendidikan di daerahnya sesuai dengan karakteristik di daerahnya masing-masing dan dengan melibatkan keikutsertaan masyarakat dalam mewujudkan tujuan pendidikan.

Madrasah Aliyah Mathlaul Anwar adalah salah satu sekolah swasta yang berada di Desa Kepuh, Serang, Banten dan telah berdiri sejak tahun 1979. MA ini berada di bawah naungan Yayasan Mathlaul Anwar. Berdasarkan hasil wawancara dengan Utun Sahid salah satu tenaga pendidik di MA Mathlaul Anwar menyatakan MA Mathlaul Anwar ini sudah menerapkan manajemen berbasis madrasah di sekolahnya dan hasilnya sudah cukup baik, salah satunya dilihat dari adanya beberapa siswa yang dapat melanjutkan pendidikan di perguruan tinggi negeri maupun swasta. Bahkan ada beberapa siswanya yang dapat melanjutkan studi dengan program beasiswa tahfidz di luar negri. Hal ini menunjukkan bahwa meskipun berada di pelosok kota Serang, Banten, MA Mathlaul Anwar mampu bersaing dengan sekolah lain yang berada di pusat kota. Tentu hal itu tidak terlepas dari adanya manajemen yang baik di Madrasah tersebut. Berdasarkan uraian yang dipaparkan di atas, maka penulis tertarik untuk meneliti implementasi manajemen berbasis madrasah dalam meningkatkan output/lulusan siswa di Madrasah Aliyah Matlaul Anwar Kepuh, Serang, Banten

\section{METODE PENELITIAN}

Penelitian ini menggunakan metode kualitatif dengan jenis penelitian bersifat deskriptif, yaitu penelitian yang menghasilkan data berupa transkrip dari jawaban narasumber untuk menggambarkan secara tepat mengenai suatu keadaan, sifat-sifat individu atau gejala yang terjadi terhadap kelompok tertentu. Selanjutnya, teknik pengambilan sampel yang digunakan dalam penelitian ini adalah purposive sampling, 
yaitu cara pengambilan sampel yang dilakukan secara sengaja sesuai dengan kriteria sampel. Kriteria sampel yang dimaksud dalam penelitian ini adalah orang yang memahami, mengetahui, dan mengalami permasalahan yang diteliti. Dalam penelitian kualitatif tidak menekankan pada jumlah atau keterwakilan, tetapi lebih kepada kualitas informasi, kredibilitas dan kekayaan informasi yang dimiliki oleh narasumber atau partisipan. Sampel dengan jumlah yang banyak tidak akan mempunyai arti jika responden tidak berkualitas dan tidak kredibel. ${ }^{5}$ Pada proses pengolahan data kualitatif dibutuhkan metode yang valid dalam menganalisis data agar memperoleh hasil penelitian yang lengkap, tepat, dan benar. Analisis yang digunakan dalam peneletian ini adalah analisis interaktif Miles dan Huberman ${ }^{6}$ yaitu dengan Mereduksi data, penyajian data, dan penarikan kesimupulan atau verifikasi data yang mana hal ini dilakukan untuk menjawab rumusan masalah penelitian.

\section{PEMBAHASAN}

\section{Implementasi Manajemen Berbasis Madrasah MA Mathlaul Anwar Kepuh}

Dalam penelitian ini ada enam komponen yang dikelola dengan baik dalam manajemen berbasis madrasah dalam meningkatkan kualitas lulusan atau output siswa, yaitu manajemen kurikulum dan pembelajaran, manajemen peserta didik, manajemen pendidik dan tenaga kependidikan, manajemen sarana dan prasarana, manajemen pembiayaan, manajemen hubungan sekolah dan masyarakat. ${ }^{7}$ Penjelesan selengkapnya mengenai masing-masing komponen manajemen berbasis madrasah di MA Mathlaul Anwar Kepuh Serang Banten akan dijelaskan seperti berikut ini:

1. Manajemen Kurikulum

Manajemen kurikulum dan pembelajaran merupakan bagian dari manajemen berbasis madrasah dalam upaya peningkatan kualitas lulusan siswa. Manajemen kurikulum dan program pembelajaran mencakup kegiatan perencanaan,

${ }^{5}$ Conny R. Setiawan, Metode Penelitian Kualitatif: Jenis, Karakteristik dan Keunggulan (Jakarta: Grasindo, 2010), hlm. 115.

${ }^{6}$ Sugiyono, "Metode Penelitian.... hlm.337.

${ }^{7}$ Imroatu Sholekhah, "Implementasi Manajemen Berbasis Madrasah (MBM) di MTs Ibnul Qoyyim Puteri Berbah Sleman Yogyakarta”, skripsi, Fakultas Tarbiyah UIN Sunan Kalijaga Kôgyakarta, 2009. 
pelaksanaan, dan penilaian kurikulum. Perencanaan dan pengembangan kurikulum nasional pada umumnya telah dilaksanakan oleh kementrian pendidikan di tingkat pusat. Namun, hal yang paling penting adalah bagaimana sekolah merealisasikan dan menyesuaikan kurikulum tersebut dengan kegiatan pembelajaran. Di samping itu, sekolah juga bertugas dan berwenang untuk mengembangkan kurikulum muatan lokal sesuai dengan kebutuhan masyarakat lingkungan setempat. Di MA Mathlaul Anwar Kepuh Serang Banten, manajemen di bidang kurikulum dilaksanakan oleh wakil kepala madrasah bagian kurikulum dan pengajaran yaitu Bapak Burhanuddin, SE. Manajemen kurikulum merupakan seluruh kegiatan yang berkaitan dengan penyelenggaraan kegiatan pembelajaran di madrasah, yang meliputi:

a) Perencanaan Kurikulum

Pengkajian Kurikulum, Secara umum program kurikulum MA Mathlaul Anwar Kepuh hampir sama dengan program kurikulum yang ada di madrasahmadrasah pada umumnya. Kurikulum MA Mathlaul Anwar Kepuh diselenggarakan dengan mengikuti kalender pendidikan yang berlaku pada setiap tahun pelajaran. Kalender pendidikan adalah pengaturan waktu untuk kegiatan pembelajaran peserta didik selama satu tahun ajaran yang mencakup permulaan tahun pelajaran, minggu efektif belajar, waktu pembelajaran efektif, dan hari libur. Kalender pendidikan MA Mathlaul Anwar Kepuh disusun dan disesuaikan setiap tahun oleh madrasah untuk mengatur waktu kegiatan pembelajaran. Pengaturan waktu belajar mengacu kepada standar isi, karakteristik sekolah, kebutuhan peserta didik dan masyarakat, serta ketentuan dari pemerintah pusat atau pemerintah daerah. ${ }^{8}$ Karena MA Mathlaul Anwar Kepuh adalah lembaga pendidikan yang berciri khas pendidikan agama Islam, tentunya mempunyai muatan lebih pada pendidikan agama.

Penyusunan Program Kurikulum, setelah pengkajian kurikulum dalam perencanaan kurikulum, MA Mathlaul Anwar melakukan penyusunan program kurikulum. Penyusunan program kurikulum di MA Mathlaul Anwar disesuaikan dengan kebutuhan siswa dan keaadan lingkungan di MA Mathlaul Anwar

8 Modul kurikulum MA Mathlaul Anwar Kepuh Serang Banten 
Kepuh. Selain itu dalam penyusunan kurikulum yang berlaku di MA Mathla'ul Anwar Kepuh beberapa hal yang menjadi acuan seperti peningkatkan keimanan dan ketakwaan, yang dilakukan dengan mengisi mata pelajaran yang dapat menunjang peningkatan keimanan dan ketakwaan. Perkembangan ilmu pengetahuan, teknologi, dan seni, dan mengacu pada kondisi sosial budaya masyarakat setempat.

Penyusunan Analisis Mata Pelajaran, Penyusunan analisis mata pelajaran merupakan perencanaan tentang apa yang akan dilakukan pada saat kegiatan pembelajaran. MA Mathlaul Anwar Kepuh dalam analisis materi pelajaran mengacu pada visi, misi, dan tujuan MA Mathlaul Anwar Kepuh Serang Banten

b) Penilaian Kurikulum

1) Penilaian Proses

Dalam melaksanakan penilaian pada proses pembelajaran, MA Mathlaul Anwar Kepuh telah menetapkan prinsip-prinsip penilaian yang harus dipegang oleh para guru dalam menilai proses pembelajaran, yaitu': memandang penilaian dan kegiatan pembelajaran secara terpadu, Mengembangkan strategi yang mendorong dan memperkuat penilaian sebagai cermin diri, melakukan berbagai strategi penilaian di dalam program pembelajaran untuk menyediakan berbagai jenis informasi tentang hasil belajar peserta didik, mempertimbangkan berbagai kebutuhan khusus peserta didik, mengembangkan dan menyediakan sistem pencatatan yang bervariasi dalam pengamatan kegiatan belajar peserta didik, menggunakan cara dan alat penilaian yang bervariasi. Penilaian kelas dapat dilakukan dengan cara tertulis, lisan, produk, portofolio, unjuk kerja, proyek, dan pengamatan tingkah laku, melakukan penilaian kelas secara berkesinambungan untuk memantau proses, kemajuan dan perbaikan hasil dalam bentuk ulangan harian, ulangan tengah semester, ulangan akhir semester, dan ulangan kenaikan kelas. Ulangan harian dapat dilakukan bila sudah menyelesaikan satu atau beberapa indikator, atau satu kompetensi dasar. Pelaksanaan ulangan harian dapat dilakukan dengan

\footnotetext{
${ }^{9}$ Modul Kurikulum MA Mathlaul Anwar
} 
penilaian tertulis, observasi, atau lainnya. Ulangan tengah semester dilakukan bila telah melakukan beberapa kompetensi dasar. Sedangkan ulangan akhir semester dilakukan setelah menyelesaikan semua kompetensi dasar pada semester bersangkutan. Ulangan kenaikan kelas dilakukan pada akhir semester genap dengan menilai semua kompetensi dasar semester ganjil dan genap dengan penekanan pada kompetensi dasar semester genap, Guru menetapkan tingkat pencapaian kompetensi peserta didik berdasarkan hasil belajarnya pada kurun waktu tertentu (akhir semester atau akhir tahun).

Agar penilaian berjalan secara objektif, guru harus berupaya secara optimal untuk i) memanfaatkan berbagai bukti hasil kerja peserta didik dan tingkah laku dari sejumlah penilaian, ii) membuat keputusan yang adil tentang penguasaan kompetensi peserta didik dengan mempertimbangkan hasil kerja (karya).

2) Penilaian Hasil Belajar

Penilaian hasil belajar peserta didik di MA Mathlaul Anwar Kepuh dikelompokkan berdasarkan kelompok mata pelajaran sebagaimana berikut:

a) Penilaian hasil belajar kelompok dan mata pelajaran agama dan akhlak mulia serta kelompok mata pelajaran kewarganegaraan dan kepribadian dilakukan melalui: i) pengamatan terhadap perubahan perilaku dan sikap untuk menilai perkembangan afeksi dan kepribadian peserta didik, ii) ujian, ulangan dan/atau penugasan untuk mengukur aspek kognitif peserta didik.

b) Penilaian hasil belajar kelompok mata pelajaran ilmu pengetahuan dan teknologi diukur melalui ulangan, penugasan, dan/atau bentuk lain yang sesuai dengan karakteristik materi yang dinilai.

c) Penilaian hasil belajar kelompok mata pelajaran estetika dilakukan melalui perkembangan afeksi dan ekspresi psikomotorik peserta didik.

d) Penilaian hasil belajar kelompok mata pelajaran jasmani, olahraga, dan kesehatan, dilakukan melalui: i) pengamatan terhadap perubahan perilaku dan sikap untuk menilai perkembangan afeksi dan kepribadian 
peserta didik, ii) ujian, ulangan dan/atau penugasan untuk mengukur aspek kognitif peserta didik.

Sementara penilaian hasil akhir belajar peserta didik, MA Mathlaul Anwar Kepuh menetapkan suatu standar penilaian yang disebut dengan Kriteria Ketuntasan Minimal (KKM) belajar pada masing-masing mata pelajaran. Standar penilaian ini ditetapkan berdasarkan hasil rapat Dewan Guru dan Komite Madrasah serta dengan memperhatikan kemampuan peserta didik dari hasil tes awal.

2. Manajemen Peserta Didik

a) Penerimaan Siswa Baru

Penerimaan siswa baru di MA Mathlaul Anwar Kepuh dilakukan 1 tahun sekali sebelum tahun ajaran baru. Penerimaan siswa baru ini dilakukan dengan cara open recruitment yang dibuka dengan jadwal 2 gelombang. Penerimaan siswa baru di MA Mathlaul Anwar Kepuh adalah berdasarkan pembagian rombel atau rombongan belajar. MA Mathlaul Anwar Kepuh menyediakan 2 rombongan belajar untuk calon siswa baru di mana 1 rombongan belajar terdiri dari maksimal 35 siswa. Calon siswa baru yang dinyatakan lolos dan diterima di MA Mathlaul Anwar Kepuh adalah yang memenuhi seluruh persyaratan dan memiliki nilai tertinggi sesuai dengan kuota siswa yang dibutuhkan. ${ }^{10}$

b) Pendataan Kemajuan Belajar Siswa

Calon siswa yang sudah dinyatakan lolos dan diterima di MA Mathlaul Anwar Kepuh diseleksi lagi dengan ujian membaca Al-Quran. Seleksi ini bertujuan untuk mengetahui sejauh mana kemampuan siswa baru dalam membaca AlQuran sehingga sekolah dapat memberikan bimbingan yang tepat. Bagi siswa yang sudah mampu membaca Al-Quran dengan baik dan benar akan diberikan bimbingan lanjutan berupa hafalan Qur'an atau masuk ke dalam kelompok program Tahfidz MA Mathlaul Anwar Kepuh. Bagi siswa yang belum mampu

${ }^{10}$ Hasil wawancara dengan bapak Utun Sahid. Selaku Kepala TU MA Mathlaul Anwar Kepuh 
membaca Al-Qur'an dengan baik dan benar akan diberikan bimbingan khusus tentang cara membaca Al-Qur'an yang baik dan benar. ${ }^{11}$

Kemudian untuk mengetahui sejauh mana kemajuan belajar siswa secara umum, guru melakukan pendataan kemajuan belajar dari masing-masing siswa dalam bentuk buku raport. Data kemajuan belajar siswa dalam bentuk raport ini wajib dilaporkan kepada orang tua atau wali murid secara periodik. Di MA Mathlaul Anwar Kepuh sendiri, pembagian raport dilakukan setiap satu semester sekali.

c) Bimbingan dan Pembinaan

Bimbingan dan pembinaan merupakan salah satu program yang diberikan kepada seluruh siswa di MA Mathlaul Anwar Kepuh di luar jam pelajaran/KBM demi tercapainya tujuan MA Mathlaul Anwar Kepuh. Bimbingan dan pembinaan yang diberikan oleh MA Mathlaul anwar yaitu: ${ }^{12}$

1) Kegiatan-kegiatan keagamaan seperti, dilakukan pelatihan BTA (Baca Tulis Al-Quran) bagi siswa siswi yang belum bisa membaca dan menulis $\mathrm{Al}$ Quran secara baik dan benar, mengadakan bimbingan secara khusus sebelum kegiatan belajar mengajar di kelas dimulai berupa tadarus dan berdoa bersama. Tujuannya adalah agar siswa dan siswi di MA Mathlaul Anwar Kepuh terbiasa membaca Al-Quran dalam kesehariannya.

2) Memberikan bimbingan dan pembinaan berupa pelatihan penggunaan teknologi seperti pelatihan penggunaan internet, pembuatan blog, penggunaan media social dan pelatihan mengoperasikan Ms.word, Ms.excel, dan Ms.power point yang diberikan kepada pengurus OSIS dan anggota jurnalis MA Mathlaul Anwar Kepuh.

3) Memberikan bimbingan les belajar siswa khusus untuk siswa-siswi kelas XII yang dilakukan sejak semester 1. Bimbingan ini diberikan untuk mempersiapkan siswa-siswi kelas XII dalam menghadapi UNBK. Kegiatan ini dilakukan setelah kegiatan belajar mengajar siswa selesai.

${ }^{11}$ Hasil Wawancara dengan pak Uut Sutisna. Selaku Kepala Madrasah MA Mathlaul Anwar

12 Modul Kurikulum MA Mathlaul Anwar Kepuh 
4) Bimbingan konseling, diberikan kepada seluruh siswa yang membutuhkan bimbingan khusus seperti siswa yang bermasalah atau siswa yang memiliki permasalahan individu. Bimbingan konseling ini terbuka untuk seluruh siswa pada saat di sekolah dan tidak hanya dilakukan oleh guru BK, namun dapat dilakukan oleh seluruh guru yang ada MA Mathlaul Anwar Kepuh. Tujuan bimbingan konseling ini adalah agar seluruh siswa memiliki wadah dan solusi pada setiap masalah yang dihadapi siswa.

5) Kegiatan Ekstrakurikuler yang dilaksanakan dalam dua kelompok yakni keorganisasian dan kegiatan lapangan. Kelompok keorganisasian berupa Pramuka dan kelompok lapangan meliputi olahraga (voli, Futsall, Badminton, dan Tapak suci). Adapun kelompok kesenian meliputi ekstra kurikuler kesenian yang didalamnya mencakup Kosidah, Seni Baca AlQuran, Drama, Seni Angklung, Band \& Drumband.

Selain bimbingan dan pembinaan seperti yang telah disebutkan di atas, madrasah juga memberikan pembinaan terhadap siswa yang akan melanjutkan ke perguruan tinggi. Mereka dibina sejak naik ke kelas XII. Wakil kepala urusan kurikulum bekerjasama dengan BK (Bimbingan dan Konseling), humas serta instansi lain berusaha menelusuri kemampuan dan minat siswa untuk melanjutkan ke perguruan tinggi atau bekerja. ${ }^{13}$

d) Monitoring

Bentuk monitoring yang dilaukan MA Mathlaul Anwar Kepuh adalah pengawasan terhadap segala aktifitas siswa baik di lingkungan sekolah maupun di luar lingkungan sekolah. Semua guru memiliki tanggung jawab terhadap pengawasan segala aktifitas siswa. Dengan memberikan teguran dan peringatan terhadap siswa yang melanggar peraturan dan tata tertib, diharapkan siswa senantiasa melakukan aktifitas yang baik demi terwujudnya harapan dan tujuan MA Mathlaul Anwar Kepuh. ${ }^{14}$ Selain itu bentuk monitoring yang dilakukan adalah dengan memberikan absensi siswa pada setiap jam pelajaran di kelas.

${ }^{13}$ Hasil Wawancara dengan bapak A. Saiful Qothi, SE. selaku Wakil Kesiswaan MA Mathlaul Anwar Kepuh,

${ }^{14}$ Hasil wawancara dengan Bapak Uut Sutisna, S.Pd.I, selaku Kepala MA Mathlaul Anwar Kepuh. 
Hal ini dilakukan untuk mengontrol siswa dalam mengikuti seluruh kegiatan belajar mengajar di sekolah.

3. Manajemen Tenaga Pendidik dan Kependidikan

Manajemen tenaga pendidik dan kependidikan di MA Matlaul Anwar Kepuh Serang Banten merupakan rangkaian kegiatan tentang kepengelolaan pendidik dan tenaga kependidikan dari tahap perencanaan sampai dengan tahap evaluasi. MA Mathlaul Anwar Kepuh Serang Banten dalam pengelolaan tenaga pendidik tidak melakukan banyak hal, karena untuk pengelolaan tenaga pendidik dan kependidik itu senidiri lebih banyak dilakukan oleh yayasan devisi pendidikan. ${ }^{15}$ Namun dari hal di atas bukan berarti MA Mathlaul Anwar dalam manajemen pendidik dan tenaga kependidikan tidak ada kegiatan adapun dalam pengelolaan manajemen pendidik dan kependidikan yang dilakukan di MA Mathlaul Anwar Kepuh serang Banten adalah sebagai berikut:

a. Perencanaan

Perencanaan pegawai merupakan kegiatan untuk menentukan kebutuhan pegawai baik secara kuantitatif maupun kualitatif untuk sekarang dan masa yang akan datang. MA Mathlaul Anwar Kepuh tidak melakukan perencanaan pegawai. Hal ini dikarenakan segala bentuk perencanaan pegawai dari open recruitment hingga mutasi pegawai sepenuhnya dilakukan oleh yayasan devisi Pendidikan.

b. Pembinaan dan Pengembangan

MA Mathlaul Anwar Kepuh Serang Banten dalam pembinaan dan pengembangan tenaga pendidik \& kependidikan sifatnya adalah insidental. Artinya, pembinaan dilakukan sesuai dengan kebutuhan. Dalam perjalanannya, pembinaan dan pengembangan ini tidak hanya dilakukan secara independen oleh pihak sekolah, tetapi juga bekerjasama dengan pengawas-pengawas pendidikan di tingkat daerah dan dengan sekolah-sekolah lain yang setingkat. Adapun bentuk pembinaan yang diikuti seperti, workshop tentang profesionalitas guru yang di adakan oleh Kemenag Kabupaten Serang dan Pelatihan cara membuat silabus yang diadakan oleh yayasan.

15 Ibid,. 
c. Penilaian dan Evaluasi

Untuk mengetahui sejauh mana kinerja tenaga pendidik dan kependidikan, MA Mathlaul Anwar Kepuh Serang Banten melakukan penilaian dan evaluasi sebagai berikut:

Tabel 1. Bentuk Penilaian dan Evaluasi MA Mathlaul Anwar Kepuh

\begin{tabular}{|c|l|l|}
\hline No & $\begin{array}{l}\text { Bentuk penilaian dan } \\
\text { evaluasi }\end{array}$ & $\begin{array}{l}\text { Periode penilaian dan } \\
\text { evaluasi }\end{array}$ \\
\hline 1 & Melalui buku laporan & Sebulan sekali \\
\hline 2 & Evaluasi periodic & $\begin{array}{l}\text { Awal tahun ajaran baru, pra \& } \\
\text { pasca UTS, pra \& pasca UAS, } \\
\text { tahap kenaikan kelas }\end{array}$ \\
\hline 3 & Evaluasi incidental & Insidental \\
\hline
\end{tabular}

Penilaian dan evaluasi melalui buku laporan dilakukan setiap sebulan sekali oleh semua guru. Semua guru memiliki buku laporan yang isinya adalah sejauh mana materi yang telah disampaikan kepada siswa. Buku tersebut dilaporkan kepada kepala madrasah setiap satu bulan sekali, sehingga kepala madrasah dapat mengetahui sejauh mana guru menyampaikan materinya dan kendala apa saja yang dihadapi oleh guru selama mengajar di kelas. Kemudian evaluasi periodik dilakukan selama 6 kali setiap tahun. Tujuan dari evaluasi ini adalah untuk mengetahui sejauh mana pendidik dan tenaga kependidikan melaksanakan tugasnya, kendala apa saja yang dialami selama pelaksanaan tugas, sekaligus mengevaluasi apa saja yang perlu dilakukan untuk kedepannya demi tercapainya tujuan yang telah ditentukan pada tahap perencanaan. Evaluasi insidental dilakukan apabila ada hal-hal atau kejadian darurat yang membutuhkan keputusan dari seluruh tenaga pendidik dan kependidikan. Selain itu evaluasi insidental dilakukan apabila akan diadakannya kegiatan-kegiatan tertentu di luar kegiatan belajar mengajar. 


\section{Manajemen Sarana Prasarana}

Hasil pengamatan yang dilakukan, pelaksanaan manajemen sarana dan prasarana di MA Mathlaul Anwar Kepuh Serang Banten berjalan dengan baik, hal ini dapat dilihat dari fasilitas sarana dan prasarana yang tersedia di MA Mathlaul Anwar Kepuh Serang Banten telah memadai seperti gedung madrasah, ruang kelas, meja kursi, tempat ibadah, tempat olahraga, serta media pembelajaran lainya. Pelaksanaan manajemen sarana dan prasarana yang baik tentunya diperlukan untuk dapat meningkatkan semangat siswa dalam belajar dan beraktifitas di sekolah sehingga diharapkan mampu meningkatkan prestasi siswa. Idealnya kegiatan yang dilakukan dalam manajemen sarana dan prasarana meliputi ${ }^{16}$, Perencanaan sarana dan prasarana, pengadaan sarana dan prasarana, inventarisasi, pengawasan dan pemeliharaan, penghapusan sarana dan prasarana

Namun MA Mathlaul Anwar Kepuh dalam manajemen atau kepengelolaan sarana dan prasarana tidak banyak melakukan kegiatan seperti di atas. Hal yang dilakukan MA Mathlaul Anwar Kepuh dalam kepengelolaan sarana dan prasarana adalah mengontrol dan melaporkan kepada yayasan apabila ada sarana dan prasarana yang dibutuhkan atau perlu ada perbaikan. Hal ini telah menjadi ketentuan dari Yayasan Mathlaul Anwar yang menaungi MA Mathlaul Anwar Kepuh.${ }^{17}$ Pelaksanaan manajemen sarana dan prasarana, yang dalam hal ini dilakukan sekolah adalah sebatas melakukan kontrol, telah berjalan dengan lancar karena didukung dan ditunjang oleh beberapa faktor seperti rasa memiliki yang tinggi oleh para guru. Dengan hal tersebut, peran serta para guru dalam menggunakan dan menjaga sarana dan prasarana sekolahpun dapat dikatakan baik. Namun meski demikian, ada beberapa hambatan yang harus dihadapi sekolah terkait dengan pelaksanaan manajemen sarana dan prasarana yaitu, penggunaan lapangan sekolah yang masih tergabung dengan MI dan MTs dan fasilitas toilet antara guru dan siswa masih bersamaan.

${ }^{16}$ Nazaruddin, Madrasah dan Perubahan Sosial Analisis Sistemik Terhadap Peran Madrasah dalam Menyikapi Krisis Moral di Era Informasi Global”, jurnal quantum Vol. 1, No. 1, Januari-April, Mdrasah Development Centre, Sumatra Selatan, 2006, hal. 125

17 Wawancara dengan Pak Uut Sutisna, selaku kepala madrasah MA Mathlaul Anwar 
5. Manajemen Keuangan atau Pembiayaan Pendidikan

Pengelolaan keuangan di MA Mathlaul Anwar Kepuh dilakukan oleh bagian keuangan yaitu ibu Sa'atu Adhiah. S.Sos. Manajemen keuangan di MA Mathlaul Anwar Kepuh merupakan bagian dari kegiatan pembiayaan pendidikan yang secara keseluruhan menuntut kemampuan sekolah untuk merencanakan, melaksanakan, dan mengevaluasi serta mempertanggung jawabkan secara efektif dan efisien. Pelaksanaan manajemen keuangan di MA Mathlaul Anwar meliputi kegiatan sebagai berikut:

a. Perencanaan Keuangan

Perencanaan keuangan yang dilakukan oleh bagian keuangan MA Mathlaul Anwar adalah meliputi penyusunan anggaran dan pengembangan rencana anggaran sekolah. Perencanaan keuangan tersebut dituangkan dalam bentuk RAB (Rencana Anggaran dan Belanja) Madrasah yang disusun sebelum memasuki tahun ajaran baru. ${ }^{18}$ Penyusunan anggaran yang dilakukan adalah dengan mengidentifikasi tujuan dan menentukan prioritas kebutuhan yang diperlukan oleh sekolah. Tujuan dari penyusunan anggaran itu sendiri adalah sebagai pedoman pengumpulan dana dan pengeluarannya, juga sebagai pembatasan dan pertanggungjawaban sekolah terhadap seluruh dana yang diterima.

b. Pelaksanaan Keuangan

Sesuai hasil wawancara dengan ibu Sa'atu Adhihah. S.Sos, pelaksanaan keuangan di MA Mathlaul Anwar Kepuh mengacu kepada RAB (Rencana Anggaran dan Belanja) Madrasah yang telah disusun dan disepakati bersama. Sumber pendanaan utama sekolah adalah dari dana BOS (Bantuan Operasional Sekolah) yang diberikan oleh pemerintah. Sementara sumber pendanaan lain adalah berasal dari orang tua siswa atau wali murid. Kemudian penggunaan sumber dana tersebut dialokasikan untuk pos-pos tertentu yang menjadi prioritas kebutuhan sekolah. Adapun pos-pos tersebut adalah ${ }^{19}$ :

1) Pengembangan perpustakaan

18 Wawancara dengan Ibu Sa'atu Adhihah. S.Sos, selaku bendahara MA Mathlaul Anwar

${ }^{19}$ Buku RAB MA Mathlaul Anwar Kepuh Serang Banten 
2) Penerimaan Peserta Didik Baru (PPDB)

3) Kegiatan pembelajaran dan ekskul

4) Pembelian Bahan Habis Pakai

5) Biaya langganan jasa

6) Pembayaran honorarium

7) Pengembangan guru dan tenaga kependidikan

8) Sarana dan prasarana

9) Beasiswa tidak mampu \& berprestasi

10) Pembiayaan pengelolaan BOS

11) Undangan dan ta'ziah

12) Lain-lain (Konsumsi, transport dinas, transport guru jauh)

Sebagai bentuk transparansi sekolah terhadap stakeholder, dalam hal ini orang tua siswa, sekolah biasanya menyampaikan RAB yang telah disusun kepada orang tua siswa atau wali murid agar mereka juga mengetahui arah dan penggunaan dana yang mereka berikan. ${ }^{20}$

c. Pengevaluasian Keuangan

Pelaksanaan evaluasi yang dilakukan di MA Mathlaul Anwar Kepuh selalu dilaksanakan pada akhir tahun ajaran guna mendapatkan informasi tentang hasil dari kegiatan pengalokasian dana, dimana informasi hasil ini kemudian akan dibandingkan dengan sasaran yang telah ditetapkan. Kemudian hasil tersebut dievaluasi bersama-sama dengan Kepala sekolah, bendahara sekolah, dan seluruh dewan guru. ${ }^{21}$ Adapun evaluasi pembiayaan tersebut hanya dilakukan oleh pihak sekolah saja, tanpa menghadirkan pihak luar. Pertanggungjawaban dana di MA Mathlaul Anwar Kepuh tergolong baik. Hal ini disebabkan sekolah rutin melakukan pertanggungjwaban penggunaan biaya kepada orang tua siswa setiap satu tahun sekali. Sedangkan bentuk evaluasi internal kepengelolaan keuangan sekolah di MA Mathlaul Anwar dilakukan setiap bulan sekali oleh bagian keuangan. Dalam hal ini bendahara sekolah melakukan rekapan mengenai pemasukan dan pengeluaran yang sudah terlaksana, sehingga bisa diketahui 
kesesuaian antara rencana dengan apa yang telah dilakukan. Hal ini dilakukan secara rutin sebagai bentuk kontrol terhadap penggunaan dana sekolah.

6. Manajemen Hubungan Masyarakat

Pada dasarnya hubungan dengan masyarakat (humas) yang juga dikenal dengan public relation merupakan kegiatan untuk menanamkan dan memperoleh pengertian, dukungan, kepercayaan, dan penghargaan dari masyarakat. Secara khusus, manajemen humas adalah segala penataan yang berkaitan dengan kegiatan hubungan madrasah dengan masyarakat yang ditujukan untuk menunjang proses belajar mengajar di madrasah. Dalam rangka melancarkan pengembangan madrasah, hubungan masyarakat mempunyai peranan yang signifikan, meliputi hubungan madrasah dengan orang tua wali, masyarakat sekitar madrasah, dan dengan instusi-instusi lainya. Selain itu, untuk membina hubungan yang baik dengan masyarakat, madrasah dituntut untuk kreatif menciptakan media yang dapat merekatkan hubungan madrasah dengan masyarakat, diantara jalan yang ditempuh MA Mathlaul Anwar Kepuh Serang Banten untuk mewujudkanya yaitu: ${ }^{22}$

a. Membentuk majelis madrasah

b. Membentuk ikatan alumni MA Mathlaul Anwar melalui laman facebook dan twitter

c. Membuat pusat informasi seputar MA Mathlaul Anwar Kepuh melalui laman web www.almapuh.co.id

d. Mengupayakan adanya program pengabdian masyarakat

e. Membina hubungan dengan lembaga-lembaga lain yang sederajat

f. Membina hubungan dengan lembaga-lembaga pendidikan lain pada jenjang menengah pertama

g. Membina hubungan dengan perguruan tinggi, bimbingan belajar, dan lembaga atau instansi khursus

h. Membina hubungan dengan Kelompok Kerja Madrasah (KKM)

i. Mendelegasikan guru dan siswa dalam tugas tertentu, seperti mengikuti turnamen, lomba-lomba pramuka, paskibra dan lainnya, seminar, MGMP dan lain-lain

${ }^{22}$ Modul Kurikulum MA Mathlaul Anwar Kepuh Serang Banten. 
j. Mengadakan kegiatan Gebyar MA setiap tahun

Dengan melalui berbagai media sebagaimana di atas, madrasah mencoba untuk selalu dekat dengan masyarakat dan membuka jalur komunikasi selebar lebarnya dengan warga dan masyarakat sekitar. Dengan begitu diharapkan akan terjadi kerjasama yang baik dan hubungan yang saling menguntungkan antara madrasah dengan masyarakat. Madrasah yang menerapkan MBM memiliki karakteristik bahwa partisipasi warga madrasah dan masyarakat merupakan bagian kehidupanya. Hal ini dilandasi oleh keyakinan bahwa makin tinggi tingkat prestasi maka makin besar rasa memiliki. Semakin besar rasa memiliki, maka semakin besar rasa tanggung jawab, dan makin besar tanggung jawab makin meningkat tingkat dedikasinya.

\section{Hasil Implementasi Manajemen Berbasis Madrasah dalam Meningkatan Output/1ulusan Siswa.}

Hasil observasi di MA Mathlaul Anwar dan hasil wawancara dengan tenaga pendidik dan kependidikan yang telah dilaksanakan, bahawa implementasi Manajemen Berbasis Madrasah di MA Mathlaul Anwar Kepuh dalam peningkatan output atau lulusan siswa di MA Mathlaul Anwar mengalami peningkatan. Dengan adanya pemberian otomi yang luas terhadap kepala madrasah yang dibuktikan dengan, Kepala madrasah adalah pemilik keputusan tertinggi di MA Mathlaul Anwar Kepuh. Kemudian adanya partisipasi dukungan dari masyarakat atau orang tua terhadap segala bentuk kegiatan yang dilakukan oleh MA Mathlaul Anwar dan adanya kerja sama yang baik dan transparan antara tenaga pendidik dan kependidikan, sehingga mampu meningkatkan output atau lulusan siswa. ${ }^{23}$

Terlihat jelas dari apa yang dipaparkan di atas bahwa implementasi manajemen berbasis madrasah di MA Mathlaul Anwar dalam peningkatan output atau lulusan mengalami peningkatan. selain obesrvasi dan wawancara peneliti juga melakukan cek data guna mengetahui secara langsung bahwa peningkatan dalam output atau lulusan di MA Mathlalul Anwar kepuh mampu bersaing dengan sekolah lain. Adapun data hasil prestasi MA Mathlaul Anwar Kepuh dapat dilihat pada tabel berkut ini:

\footnotetext{
${ }^{23}$ Wawancara dengan Pak Uut Sutisna, selaku Kepala Madrasah MA Mathlaul Anwar Kepuh,
} 
Tabel 2. Prestasi MA Mathlaul Anwar Kepuh Serang Banten

\begin{tabular}{|c|l|c|}
\hline No & \multicolumn{1}{|c|}{ Prestasi } & Tahun \\
\hline 1 & Juara II Nasyid tingkat provinsi & 2014 \\
\hline 2 & $\begin{array}{l}\text { Juara II Pidato Bahasa Arab tingkat } \\
\text { provinsi }\end{array}$ & 2014 \\
\hline 3 & $\begin{array}{l}\text { Juara I MSQ Putra tingkat } \\
\text { kabupaten }\end{array}$ & 2015 \\
\hline 4 & Juara I MSQ Putra tingkat provinsi & 2015 \\
\hline 5 & $\begin{array}{l}\text { Juara II Festival Band untuk umum } \\
\text { yang diselenggarakan oleh SMP 1 } \\
\text { Cinangka }\end{array}$ & 2015 \\
\hline 6 & $\begin{array}{l}\text { Juara II Volley Ball tingkat } \\
\text { kabupaten }\end{array}$ & 2016 \\
\hline 7 & \begin{tabular}{l} 
Juara I Jambore MA tingkat nasional \\
\hline 8
\end{tabular} & $\begin{array}{l}\text { Juara II Bulu Tangkis tingkat } \\
\text { kabupaten }\end{array}$ \\
\hline 9 & $\begin{array}{l}\text { Juara II Tari Saman tingkat } \\
\text { Jabodetabek }\end{array}$ & 2016 \\
\hline 10 & $\begin{array}{l}\text { Juara III OLIPS Tingkat Kabupaten } \\
\text { Serang }\end{array}$ & 2017 \\
\hline
\end{tabular}

Dari tabel di atas terlihat dari tahun 2014 sampai 2017 MA Mathlaul Anwar mengalami peningkatan dalam pencapain prestasi non akademik. Peningkatan tersebut dari meningkatnya jumlah prestasi yang dicapai selain itu juga meningkat dari segi tingkatan perlombaan. Di tabel terlihat jelas pada tahun 2014 hanya meraih 2 perlombaan dan pada tahun 2015 ada 3 kejuaran yang diperoleh. Selain itu pada tahun 2016 jumlah kejuaran yang dicapai menurun hanya dua namun pada tahun 2016 MA Mathlaul meraih prestasi pada tingkat nasioal yang sebelumnya belum pernah tercapai. Selain prestasi nonakademik yang diraih, implementasi manajemen berbasis madrasah dilihat dari hasil nilai ujian nasional di MA Mathlalu Anwar belum mampu memberikan peningkatan dalam bidang akademik, hal tersebut dapat dilihat pada tabel 8 Hasil Nilai UN Siswa Mathlaul Anwar Kepuh Tahun 2014-2017 
Tabel 3. Hasil Nilai UN MA Mathlaul Anwar Kepuh Tahun 2014-2017

\begin{tabular}{|c|c|c|c|c|c|}
\hline Maple & 2014 & 2015 & 2016 & 2017 & 2018 \\
\hline B.Indo & 6,4 & 56,66 & 50,45 & 51,85 & 51,0 \\
\hline Matematika & 6,2 & 32,35 & 21,36 & 22,50 & 47,0 \\
\hline B.Inggris & 5,6 & 45,09 & 38,95 & 27,74 & 36,8 \\
\hline Pilihan & 7,2 & 40,24 & 42 & 46 & 50,7 \\
\hline
\end{tabular}

Dari data hasil observasi, wawancara dan dokumentasi terlihat bahwa dengan implementasi manajemen berbasis madrasah dapat meningkatan output/ lulusan siswa. ${ }^{24}$ Selain hal tersebut MA Mathlaul Anwar dalam mengimplemntasikan manajemen berbasis madrasah dalam peningkatan mutu lulusan terlaksana dengan baik, dilihat dari adanya beberapa siswa yang dapat melanjutkan pendidikan di perguruan tinggi negeri maupun swasta. Bahkan ada beberapa siswanya yang dapat melanjutkan studi dengan program beasiswa tahfidz di luar negri. ${ }^{25}$

\section{KESIMPULAN}

1. Implementasi manajemen berbasis madrasah di MA Mathlaul Anwar Kepuh Serang Banten meliputi, manajemen kurikulum, manajemen peserta didik, manajemen tenaga pendidik dan kependidikan, manajemen sarana dan prasarana, manajemen keuangan, dan manajemen hubungan dengan masyarakat berjalan dengan baik dari perencanaan hingga evaluasi.

2. Hasil implementasi manajemen berbasis madrasah dalam meningkatkan output/lulusan siswa di MA Mathlaul Anwar Kepuh yaitu:

24 Wawancara dengan pak Utun Sahid selaku Tenaga Kependidikan MA Mathlaul Anwar Kepuh 25 Ibid... 
a. Mampu meningkatkan prestasi non akademik siswa dilihat dari meningkatnya prestasi yang diraih MA Mathlaul Anwar Kepuh

b. Belum mampu meningkatkan prestasi akademik di MA Mathlaul Anwar dilihat dari tidak meningkatnya nilai UN dari tahun sebelumnya.

c. MA Mathlaul Anwar dalam mengimplemntasikan manajemen berbasis madrasah dalam peningkatan mutu lulusan terlaksana dengan baik, dilihat dari adanya beberapa siswa yang dapat melanjutkan pendidikan di perguruan tinggi negeri maupun swasta. Bahkan ada beberapa siswanya yang dapat melanjutkan studi dengan program beasiswa tahfidz di luar negri

\section{DAFTAR PUSTAKA}

Arikunto, Suharsimi, Prosedur Penelitian, Suatu Pendekatan Praktik, Jakarta: Rineka Cipta, 2010.

Awaluddin, Tjala, "Potret Mutu Pendidikan Indonesia Ditinjau dari Hasil-hasil Studi Internasional", journal of repository.ut.ac.id, 2008.

Bafadal, Ibrahim, Manajemen Perlengkapan Sekolah Teori dan Aplikasinya, Jakarta: Grafika Offset, 2003.

Barnawi dan M. Arifin, Sistem Penjamin Mutu Nasional, Yogyakarta: Ar Ruzz Media, 2017).

Dikmenum, Peningkatan Mutu Pendidikan Berbasis sekolah: Suatu Konsepsi Otonomi Sekolah.

E Mulyasa, Manajemen Berbasis Sekolah, (Bandung: PT Remaja Rosdakarya, 2002).

Fattah, Nanang, Landasan Manajemen Pendidikan, Bandung: PT. Remaja Rosdakarya, 2000.

Kasanah, Istinari Rukun "Implementasi Manajemen Berbasis Sekolah Di MIN Jejeran Bantul Yogyakarta” skripsi, Fakultas Dakwah, 2009.

Kosasi, Achmad "Implementasi Manajemen Berbasis Sekolah Di MTsN Bantul Kota Yogyakarta” Skripsi, Fakultas Ilmu Tarbiyah dan Keguruan, 2009.

Kurniadin, Didin dkk., Manajemen Pendidikan Konsep \& Prinsip Pengelolaan Pendidikan, Bandung: AR-RUZZ MEDIA, 2009.

Masaong, Abd. Kadim, Supervisi Pembelajaran dan Pengembangan Kapasitas Guru, Bandung: Alfabeta, 2012.

Masruroh, Siti, "Manajemen Peningkatan Mutu Berbasis Madrasah Di MTs Negri Karanganyar Purbalingga”, Skripsi, Purwokerto: Fakultas Ilmu Tarbiyah dan Keguruan IAIN Purwokerto, 2016. 
Mulyasa, Pedoman Manajemen Berbasis Madrasah, (Jakarta: Departemen Agama RI. Jakarta, 2005).

Mulyasa, Menjadi Kepala Madrasah; Profesional Dalam Konteks Menyukseskan MBS dan KBK, (Bandung: Remaja Rosdakarya, 2003).

Musfah, Jejen, Manajemen Pendidikan Teori, Kebijakan, dan Praktik, Jakarta: Prenadamedia Group, 2015.

Mustari, Mohammad, Manajemen Pendidikan, Jakarta: Rajawali Pers, 2015.

Nasrullah, Saddam Agung "Implementasi Manajemen Berbasis Madrasah (Studi Kasus Pada MIN Jejeran Bantul Yogyakarta Tahun 2013-2014)”, Skripsi, Fakultas Ilmu Tarbiyah dan Keguruan, 2016.

Noor, Juliansyah, Metodologi Penelitian, Jakarta: Kencana Prenada Media Group, 2012.

Nurkholis, Manajemen Berbasis Sekolah teori, model, dan aplikasi, (Jakarta: PT. Gramedia Widiasaran Indonesia, 2003).

Puslitbang Pendidikan Agama dan Keagamaan Badan Litbang Agama dan Diklat Keagamaan, Konsep Dasar Manajemen Madrasah Mandiri, (Jakarta: Puslitbang Pendidikan Agama dan Keagamaan, 2003).

Setiawan, Conny R., Metode Penelitian Kualitatif: Jenis, Karakteristik dan Keunggulan, Jakarta: Grasindo, 2010.

Sholekhah, Imroatu "Implementasi Manajemen Berbasis Madrasah (MBM) di MTs Ibnul Qoyyim Puteri Berbah Sleman Yogyakarta", skripsi, Fakultas Tarbiyah UIN Sunan Kalijaga Yogyakarta, 2009.

Soleha, Rodhi “ Implementasi Manajemen Berbasis Madrasah (MBM) Pada Program Ketrampilan Hidup Mandiri (KHM) Di MAN Godean Sleman Yogyakarta”, skripsi, Fakultas Tarbiyah UIN Sunan Kalijaga Yogyakarta, 2009.

Sugiyono, Metode Penelitian Pendidikan, Bandung: Alfabeta, 2017.

Tim Dosen Admnistrasi Pendidikan Universitas Pendidikan Indonesia, Manajemen Pendidikan, Bandung: Alfabeta 2013.

Tim Dosen MPI, Pedoman Penulisan Skripsi Program Studi Manajemen Pendidikan Islam, Yogyakarta: Prodi MPI Fakultas Ilmu Tarbiyah dan Keguruan UIN Sunan Kalijaga Yogyakarta, 2014.

Yusuf, Umar, Manajemen Pendidikan Madrasab Bermutu, Bandung: Refika Aditama, 2016.

Zaini, Muhammad, "Manajemen Peningkatan Mutu Pendidikan Berbasis Madrasah", Disertasi, Malang: Universitas Islam Negri Maulana Malik Ibrahin Malang, 2016.

Zazin, Nur, Gerakan Menata Mutu Pendidikan Teori \& Aplikasi, Yogyakarta: AR-RUZZ MEDIA, 2011 